\title{
Radicalism Prevention through Propaganda Awareness on Social Media
}

\section{Pencegahan Paham Radikal dengan Propaganda Awareness pada Media Sosial}

\author{
Yani Tri Wijayanti \\ UIN Sunan Kalijaga Yogyakarta, Jl. Laksda Adisucipto, Sleman \\ e-mail: yani.wijayanti.uin-suka.ac.id
}

\begin{abstract}
Dissemination of information through social media is prone to high school students because of its high social media usage activities. Students need to have propaganda awareness (awareness of the existence of propaganda practices), which is mainly disseminated through news or other media content. By having propaganda awareness, students can analyze information or news, so they can sift essential information, including information that they wish to redistribute. This research used a mixed method. The data was collected with a focus group discussion and propaganda test to students of State Madrasah Aliyah (MAN) in the Yogyakarta Special Province. The result of the propaganda test before the simulation showed the strong influence of the media on student attitudes. After simulation and retesting, the effect decreased significantly. Propaganda awareness can be a provision for students to be more alert in filtering information from social media that contain radicalism.
\end{abstract}

Keywords: : Propaganda Warenessa; Radicalism; Social Media

\section{Abstrak}

Penyebaran informasi melalui media sosial ini, rentan pada para pelajar sekolah menengah atas karena aktivitas penggunaan media sosialnya tinggi. Pelajar perlu memiliki propaganda awareness (kesadaran akan adanya praktik propaganda) yang ada di sekitar mereka, yang terutama disebarkan melalui berita atau konten media lainnya. Dengan memiliki propaganda awareness, pelajar memiliki kemampuan dalam menganalisis sebuah informasi atau berita, sehingga dapat memilah informasi yang baik yang dibutuhkannya, termasuk ketika akan membagikan ulang informasi tersebut kepada orang-orang di sekitarnya. Penelitian ini menggunakan metode campuran, pengumpulan data dengan FGD dan Propaganda Test kepada pelajar Madrasah Aliyah Negeri (MAN) yang ada di Provinsi Daerah Istimewa Yogyakarta. Hasilnya propaganda test sebelum simulasi menunjukkan tingginya pengaruh media terhadap sikap siswa. Setelah dilakukan simulasi dan tes ulang, pengaruh itu mengalami penurunan yang signifikan. Propaganda awareness dapat menjadi bekal bagi siswa untuk berhati-hati dalam memahami informasi dari media sosial yang mengandung radikalisme.

Kata Kunci: Media Sosial; Propaganda Awareness; Radikalisme. 


\section{Introduction}

The forms of radical movements in Indonesia are varied. Apart from movements similar to Islamic State of Iraq and Al-Sham (ISIS) that recruit people to participate in wars and establish a country, some movements disseminate radicalism, containing bigotry, towards other religious groups or different branches within the same groups, such as bigotry towards Shia and Ahmadiyya, including towards the official government, political parties, until other individuals that are not in line with their faith. The dissemination is often done through mass media, notably the internet. The reason is that the internet is considered the most accessible medium that is not constrained by space and time.

According to The Spectator Index, Indonesia is a home of over 265 million people and the world's fourth most populous country (economy.okezone.com). Indonesian internet users are also numerous. Mostly the internet users in Indonesia access the internet for recreational purposes and less for informational and other purposes. One of the indications of the tendency is Indonesian high access to social media, such as Facebook and Twitter.

The high number of internet users affect human interactions. Human interaction is experiencing a shift with the advent of new media. This phenomenon, which is used for various activities and people, shows how useful social media for human interaction. The Wall Street Journal, as cited by cnnindonesia.com, reported that Indonesian Facebook users had hit 46 million users in June 2014, and it is still growing until now, with an average growth rate of $6 \%$ per year. The number put Indonesia in second place after the US for Facebook users. As for Twitter, Indonesian users had reached 50 million users per March 2015. Furthermore, based on data from ITPaintCorporation, $41 \%$ of Facebook users come from people aged 18-24 years, and 21\% from aged 25-34 years old. Suppose that those two groups of ages are combined, namely between 18-34 years, which belong to a productive age, the number can reach $62 \%$ or around 36 million users.

However, it is worth noting that although Facebook forbids children and teenagers under 17 years old to use the platform, many Indonesian students, ranging from high school to even elementary school, register to the platform by faking their identities. It is the reason that high school students in Indonesia aged 15-18 years typically have already had a Facebook account, including students who pretend their identities. The problem is, although this platform strictly regulates harmful content, such as porn, Facebook is not free from positive and negative. Positive abuse is like online selling, whereas negative abuse can range from abduction, scam, to other crimes.

Of the many facilities provided by the platform, the share button, which figures in disseminating a link of a site from an account to another, whether from the same or secondary network, accounts for one of the abuse-prone facility. It is problematic since Links distributed on social media are various, ranging from a link to an informational website, entertainment, to politics. Consequently, the spread of the links on Facebook relatively cannot be controlled, although the users can report news that violates community standards. The Indonesian Presidential Election 2014 is an example of the use of this in terms of politics; at that time, the use of sharing links about the election, ranging from official campaign to black propaganda, was prevalent, and it seemingly cannot be ceased.

However, recently, this facility is also exploited to share religious information. One of them is radical movements that take advantage of the internet for the platform of the campaign. Online media is one of the rooms used by terrorists and their supporters to 
terrorize (Fikri, 2013 in Kusuma, 2018). This movement needs to obtain proper concern since many of those not only share their religious views but also spreads radicalism thorough the share button on Facebook. In this case, adolescents, who psychologically is searching for an identity, are a group that is vulnerable to the propaganda of radicalism adherent propaganda.

The government attempts to block the website containing radicalism is considered not adequate since those websites still can be accessed. Not to mention that the owners regularly only change the domain and continue to spread the doctrine through Facebook's mediation with a new account. Protection attempts from radicalism, therefore, are necessary for adolescent users on Facebook.

With that in mind, the research aims to identify the pattern of social media consumption of students in Madrasah Aliyah Negeri (MAN/ Indonesian Islamic Public Middle School) in the Special Region of Yogyakarta. Apart from protecting the students from the spread of radicalism in the name of religion, the research also hopes that it can raise the students' propaganda awareness. The propaganda test is applied as the research method to realize the aim.

Regarding propaganda, Bernays (1928: 22) described it as "a consistent attempt to create and form an event so that the event can contaminate relations in society with a certain idea, ranging from group, organization, or company." Furthermore, for him, "propaganda will never die out. Intelligent men must realize that propaganda is the modern instrument by which they can fight for productive ends and help to bring order out of chaos (Cull et al. 2003: 319)."

Propaganda has a negative connotation. The negative reputation appeared during world war I and II when many political leaders referred to the enemies' activities as propaganda while disseminating information, evidence, and argument, for their pursuits. The disdain on propaganda, according to McQuail, happens because this term is associated with international conflicts and the war on terror. Ideally, it should be used in any field since, definitionally speaking, any communicative action that intends to reach a certain aim can be propaganda. (McQuail, 2011: 298).

Propaganda is often used to affect opinion and belief on religious issues, notably during the disunity between Catholic Rome Churches and Protestant Churches. After that event, propaganda then becomes a general term in politics. Mainly it is used to refer any attempt sponsored by the government, political group, or secret interests. At the beginning of the $20^{\text {th }}$ century, propaganda alludes to party slogans and, in another field, to public relations by industry owners.

Etymologically, propaganda is translated from a Latin word, which means "information that is needed to be distributed." In some places, propaganda is a neutral and even positive word, while, in other sites, it is understood negatively. The connotations of propaganda also vary from time to time. For example, in Portuguese-speaking and Spanish-speaking countries, propaganda commonly refers to general manipulative media, namely advertisement. It is different from the English language that initially defined propaganda as a neutral term for information dissemination in supporting a particular cause. However, because this meaning of this term shifted negatively in western countries in the $20^{\text {th }}$ century, gradually, propaganda refers to planned activities to spread false news but 'interesting.' It is usually used to support or justify a particular political ideology.

This connotation mainly emerges because Hitler and the Soviet Union explicitly use this term to support Nazism and Communism in public expression. Propaganda, as a 
political attempt to temp and stir public opinion, was exercised intensively by spreading falsehood to spread Nazism (Fascism) and expand the influence and power during World War II. Since then, propaganda obtains adverse reactions from democratic countries, mainly because Nazi propaganda had made many people lost their lives.

Dobb (1966) explained that in a democratic country, propaganda is understood as an individual's or group's activity that controls other individuals by suggestion. However, Blumer (1969) mentioned that propaganda could also be considered a political campaign aiming to invite and guide other people to accept a view, ideology, or values. Mostly, it is performed by influencing, provoking, and tempting. The difference in the definition above implies that propaganda is difficult to identify. The most challenging issue is to differentiate propaganda with other types of persuasion and avoid conflation with other meanings. A quote saying "what they do is propaganda and what we do is education" is one of the examples of the problem of clarity.

Garth Jowett and Victoria O'Donnell, nonetheless, gave a short but clear explanation of propaganda. They argued that "propaganda is an intentional and systemative attempt to shape perception, manipulate cognitions, and behavior, to realize response intended by the propagators." Richard Alan Nelson proposed another clear but broader definition. For him, propaganda is "a systemative form of persuasion that tries to affect emotion, attitude, opinion, and behavior of the target for ideological, political, or commercial purpose through message transmission controlled by a party, which can be factual or not) on mass media or direct communication channel." He then continued that a propaganda organization employs a propagator to be involved in the creation and distribution of persuasion."

Because propaganda is seen as a dangerous communication practice for humanity, many American thinkers try to understand how it works. Institute for Propaganda Analysis (IPA) then was established in 1937 to realize the aim. It was started when one of the thinkers in social psychologist, Hadley Cantril, in the 1930s, received a call from Edward A. Filene, an entrepreneur, the pioneer of credit unions the US, and the founder of Twentieth Century Fund, the day after he delivered a talk in the Boston radio station on Propaganda. Both of them agreed to make an institution that would investigate propaganda and appoint Cantril as the leader. To run the institution, Cantril involved other famous thinkers, such as Edgar Dale and Leonard Dobb.

The first IPA's work focused on study towards the speech of Coughlin, a Roman Catholic Priest. The result of the investigation was a publication The Fine Art of Propaganda (1939) edited by Alfred McClung Lee and Elizabeth Briant Lee. The book offered seven general tools for propaganda and named them interestingly so that it can be exciting when it is taught in the schools. Those seven tools are (1) Name Calling, (2) Glittering Generality, (3) Transfer, (4) Testimony, (5) Plain Folks, (6) Card Stacking, dan (7) Bandwagon. Lee and Lee (1939) explained those elements as follows:

1. Name Calling is labeling that intends to disparage an idea or person. It is used to reject and condemn something without evidence.

2. Glittering Generality is an attempt to relate something with kind words, and it is used to make the hearer accept and agree with a claim without scrutinizing the evidence. When the use of good words becomes general, the hearer tends not to notice or realize.

3. Transfer is a method to carry authority, support, and pride of a thing that is treasured to other things so that it can be accepted. Transfer works through an 
association process. Communicators in this method aim to connect or ideas or products with a thing that is valued by others. Mostly transfer is done with symbolic objects.

4. Testimony is a method that allows people that love or hate an idea, program, or product to praise or undermine the things that they love or hate. It is a technique that is normal in political campaigns. Testimony relies on the popularity and attractiveness of people who testify, especially if it is related to their field of interest or profession. For example, a testimony of a beautiful woman regarding soap that can make skin smoother will be more reliable than testimony from an athlete.

5. Plain Folks is a method to convince the audience that the ideas of the speaker and the speaker itself are good because it and he is a "part of the people" or "the common people."

6. Card Stacking is a method to select and take advantage of facts, lies, illustration, violation, and logical and unlogical statements to emphasize the best case or the wors of an idea, program, person, or product. Card stacking is similar to slanting in general semantics. This technique picks arguments and evidence that support a position and ignore other things that are not supportive of the position.

7. Bandwagon is a method to persuade a group of people by saying that other people in the same group, or everyone, are doing what the propagator is saying, and therefore, the hearer should do the same to be a part of the group.

Whether the aim of propaganda is bad or good, the public should understand that this practice still exists until now, although it is rarely apparent in communication. A propaganda practice is veiled in many communication practices, such as public relations and journalism. Therefore, the public should be capable of detecting and understanding the exercise of propaganda. Typically, it is called propaganda awareness.

Propaganda awareness has not been a popular term despite the urgency. One of the institutions that realize the importance of this awareness is the Peace and Conflict Journalism Network (PECOJON) that frequently conduct training for journalists to understand propaganda practices in their surroundings. This institution also aims to make the journalists not to be propaganda agents that spread propaganda in their coverage.

In addition, as a non-government educational organization in the USA, the iCivics also develops a model for propaganda awareness for teachers and students in the USA (www.icivics.org). Propaganda awareness of the iCivics is developed based on seven techniques identified by the Institute for Propaganda Analysis (IPA) under the leadership of Hadley Cantril, Edgard Dale, dan Leonard W. Doob.

On the other hand, Radicalism can be defined as an ism or position that strives for changes or dramatic social and political transformation with violence. In the religious perspective, radicalism is a religious belief that refers to the foundation of religion together with the level of religious fanaticism. Consequently, the adherents of radicalism normally commit to violence to actualize their religious beliefs (Sulistyo, 2014: 2). An essential process of radicalism is radicalization. Radicalization is a personal process when an individual adopts an idealism and extremely political, social, or religious aspiration 
that justifies violence and gets prepared and motivated to exercise aggressive behavior (Wilner \& Dubouloz, in Sulistyo,2014:2).

Radicalization that triggers radicalism is formed through three significant aspects, namely:

1. Individual process. Radicalization is generally seen as a process of searching for an identity. For adolescents, identity searching is a process to define someone with the world.

2. Interpersonal dynamics. Radicalization needs interpersonal interaction with other people to stimulate the people that are targeted with radicalization and influence their process of understanding.

3. Environmental influence. Narrative and political vocabularies of religious organizations that have significant impacts in society can also be narrative of radical groups (Choudhury, 2007:21).

Some social factors can trigger radicalism, and at some point, at inevitable political escalation, it can breed radical movements. Those factors are:

1. Political factors. Violence on behalf of religion is more accurately defined as a social and political symptom rather than religion. In this case, radicals see the historical fact that certain religious groups, who have similarities with them, do not benefit from global civilization. It leads to inevitable antagonism towards dominated powers. Radicalism touches religious sentiment and emotion and gathers forces to strive for the political target using religious slogans and language.

2. Religious emotion factor. Religious sentiment includes spiritual solidarity to the oppressed fellows by a specific power. In this context, religious emotion is religion as an interpretative understanding of reality.

3. Cultural factor. Society tends to dispense with a cultural network that is considered unsuitable to its culture. An example of a cultural factor for radicalism is the influence of western secularism on Islamic culture. Radicals view this idea marginalizes Islamic ideology and cultures.

4. Ideological factor. The incapability to compete in culture and organization makes radical groups commit to violence to show their existence or hegemony or their culture. One of the examples is the anti-western movement that endangers other religious groups.

5. Government policy factors. The incapability of the government to repair the frustration and anger of groups that feel oppressed by other countries' domination, ranging from military, economic, to ideological, contributes to triggering radicalism movement. The foreign press that often discredits a certain religion also makes radicals react with violence. (Hambali, in Sulistyo, 2014: 4).

\section{Methodology}

This research applied a combination method. For the qualitative data, focus group discussion was used. Focus group discussion is a systematic and guided discussion on a specific issue and problem. Irwanto (2006: 1-2) defined FGD as a systematic collection data and information process regarding a particular issue through group discussion. There 
are three keywords in an FGD: discussion, and not an interview or conversation; group, and not individual, c guided and focus, and not free. Many experts said that an FGD is used to find a solution to a problem.

For the quantitative data, the research used propaganda tests based on the iCivics model with some adaptations to the Indonesian context and topics since the targets were high school students. The test used seven questions that relate to one of the propaganda techniques proposed by the Institute for Propaganda Analysis (IPA). The students were presented a picture with three possible answers. Each answer has a different score, and the score shows the influence level of propaganda on the student.

3 points will be given to a response with the highest propaganda influence, 2 points for an answer with medium influence, and 1 point for a response with the mildest influence. The higher the score, the higher the influence of propaganda, and the less the score, the less the influence. With that in mind, the table score can be seen in Table 1 below:

Table 1. Scoring for Propaganda Influence

\begin{tabular}{clcc}
\hline No & & Score & Category \\
\hline 1 & $7-10$ point & Mild \\
\hline 2 & $11-15$ point & Medium \\
\hline 3 & $16-21$ point & High \\
\hline
\end{tabular}

\section{Results and Discussion \\ Social Media Use}

The research was performed in five Indonesian Islamic Public Middle School (Madrasah Aliyah Negeri/ MAN) located in the Special Region of Yogyakarta. Those five MANs are MAN Maguwoharjo in Sleman Regency, MAN Wonosari in Gunungkidul Regency, MAN Wates in Kulonprogo Regency, MAN 1 in Yogyakarta City, dan MAN Sabdodadi in Bantul regency. Twenty students were taken from each school so that the sample size was 100 .

\section{Internet Access}

Most of the students used the internet actively with different devices. In general, they accessed the internet with smartphones, which was being increasingly affordable, and personal computer. The computer they used can be their home computers or computers in the internet café. The data can be seen in Table 2 below:

Table 2. Source of Internet Access

\begin{tabular}{clc}
\hline No & \multicolumn{1}{c}{ Social Media } & Users $(\mathbf{N}=\mathbf{1 0 0})$ \\
\hline 1 & Personal Computer & 51 \\
\hline 2 & Smartphone & 83 \\
\hline 3 & Internet Cafe & 74 \\
\hline
\end{tabular}

sources: the researcher's data

Meanwhile, their duration in using the internet was varied. The students who had a smartphone can use the internet more flexibly with longer duration. On the other hand, students who merely used personal computers had a shorter time spent. Their duration in using the internet decreased during the school holiday. In general, the duration of internet use can be seen in Table 3 below: 
Table 3. Average Daily Time Spent Online

\begin{tabular}{clcc}
\hline No & & Duration & Users \\
\hline 1 & Under 1 hour & 10 \\
\hline 2 & $1-2$ hours & 67 \\
\hline 3 & $2-4$ hours & 18 \\
\hline 4 & Over 4 hours & 5 \\
\hline & & $\mathbf{1 0 0}$ \\
\hline
\end{tabular}

source: the researcher's data

As for the activity, the students mostly access the internet for accessing social media, gaming, and informational use, such as for school tasks and other purposes. It can be seen in Table 4 below.

Tabel 4. Online Activity

\begin{tabular}{clccc}
\hline No & \multicolumn{2}{c}{ Activity } & Users \\
\hline 1 & $\begin{array}{l}\text { Browsing (News and other informational } \\
\text { purposes) }\end{array}$ & 23 \\
\hline 2 & Social Media & 71 \\
\hline 3 & Online Game & 6 \\
\hline & & 100 \\
\hline
\end{tabular}

\section{Interaction on Social Media}

source: the researcher's data

When using social media, which, in this case, Facebook, the students mostly used almost all facilities available. Generally, it can be seen in Table 6 below:

Table 6. Activity on Facebook

\begin{tabular}{llcccc}
\hline No & \multicolumn{1}{c}{ Activity } & Often & Seldom & Never & Sum \\
\hline 1 & $\begin{array}{l}\text { Updating picture/ } \\
\text { status }\end{array}$ & 23 & 48 & 9 & 100 \\
\hline 2 & $\begin{array}{l}\text { Commenting on } \\
\text { friends' status }\end{array}$ & 71 & 2 & 100 \\
\hline 3 & Liking friends' status & 34 & 64 & 2 & 100 \\
\hline 4 & $\begin{array}{l}\text { Reading/Opening a } \\
\text { llink }\end{array}$ & 28 & 58 & 14 & 100 \\
\hline 5 & Sharing a news link & 19 & 62 & 19 & 100 \\
\hline 6 & Playing game & 14 & 54 & 32 & 100 \\
\hline
\end{tabular}

source: The researcher's data

Of 86 students that had opened or read a news link shared by their friend on Facebook(often 28, seldom 54), the type of news they tend to open is in the next table:

Table 7. Type of News

\begin{tabular}{llc}
\hline No & \multicolumn{1}{c}{ Type of News } & Sum \\
\hline 1 & Entertainment, Film, Music, Gosip & 79 \\
\hline 2 & Politics, Law, and Crime & 52 \\
\hline 3 & Religion & 43 \\
\hline \multicolumn{2}{c}{ source: The researcher's data }
\end{tabular}

However, the table above is merely a general tendency. This is because, in practice, almost all students answered opening or reading any news link as long as the 
title and the pictures intriguing. Many of them confessed they often got deceived by the titles, and it made them not finish the news. They only would share the news links if there were interesting news. However, some of them said that there was no particular reason for sharing news. The other students shared so that their friends could elicit information by reading the news.

\section{First Propaganda Test (Pre-Simulation)}

After the pattern of Facebook use has been identified, the students then were given a propaganda test consisting of 7 questions. The result can be seen in the table below. The students were not informed regarding the score of the test.

Table 8. The Result of First Propaganda Test

\begin{tabular}{ccccccc}
\hline & \multicolumn{2}{c}{ 3 Point } & \multicolumn{2}{c}{ 2 Point } & \multicolumn{2}{c}{ Point } \\
\cline { 2 - 7 } QUESTION & ANSWER & N & ANSWER & N & ANSWER & N \\
\hline 1 & B & $\mathbf{1 7}$ & A & $\mathbf{3 3}$ & C & $\mathbf{5 0}$ \\
\hline 2 & A & $\mathbf{4 2}$ & C & $\mathbf{4 8}$ & B & $\mathbf{1 0}$ \\
\hline 3 & B & $\mathbf{2 6}$ & A & $\mathbf{2 1}$ & C & $\mathbf{5 3}$ \\
\hline 4 & A & $\mathbf{3 8}$ & C & $\mathbf{3 3}$ & B & $\mathbf{2 9}$ \\
\hline 5 & B & $\mathbf{5 8}$ & C & $\mathbf{1 7}$ & A & $\mathbf{2 5}$ \\
\hline 6 & A & $\mathbf{2 7}$ & B & $\mathbf{5 0}$ & C & $\mathbf{2 3}$ \\
\hline 7 & B & $\mathbf{5 3}$ & A & $\mathbf{1 7}$ & 1 & $\mathbf{3 0}$ \\
\hline & & $\mathbf{2 6 1}$ & & $\mathbf{2 1 9}$ & & $\mathbf{2 2 0}$ \\
\hline
\end{tabular}

source: The researcher's data

The table shows that there was a strong tendency that each student was strongly affected by the media. This statement is based on the answers of the students to questions that contained specific propaganda, which can be found daily.

For example, for question number 1 regarding name-calling, the question was asked about Basuki Tjahaja Purnama (Ahok), a former Jakarta Governor, and Candidate of Special Region of Jakarta Gubernatorial Election 2017. The majority of students chose $\mathrm{C}$ (not my leader) that showed that the students had an awareness of not entering a polemic about a figure. Ahok is a candidate in another region (Jakarta) while they lived in Yogyakarta, which even does not have a governor. However, 30 students chose A (a firm leader), and 17 students ticked B (a leader that should be rejected). It implies that half of the students were exposed by the media when they gave their answers.

When the researcher asked one of the respondents that chose A, named Dicky Bayu from MAB Wonosari, he said: "... because he is courageous in executing an action." His answer is in line with Elsa Novita Sari that answered with this sentence "since he is a firm man who can manage Jakarta." On the other hand, Fauzen, who picked B, mentioned that he did not like "a leader with a Chinese mindset." Similarly, Isnaini Nurlaili Pratiwi answered that she thought that Ahok "undermines another religion."

Based on the students' answers, it is clear that the media shaped an image of someone, whether positively or negatively. Consequently, it resulted in either hate or love even though all of them are not in acquaintance with Ahok personally. All of them know Ahok from the media. In general, table 9 showed the result of the students scoring:

Table 9. The Result of First Propaganda Test $(\mathrm{N}=100)$

\begin{tabular}{ccc}
\hline No & Score & Number of Students \\
\hline 1 & Mild $(7-11$ point $)$ & 7 \\
\hline
\end{tabular}




\begin{tabular}{llc}
\hline 2 & Medium $(12-16$ point $)$ & 73 \\
\hline 3 & High $(17-21$ point $)$ & 20 \\
\hline & & 100 \\
\hline
\end{tabular}

source: The researcher's data

\section{Awareness of Propaganda Simulation}

After filling the propaganda test (without finding out the result), the students then were participated in a session called propaganda awareness by introducing them with seven techniques of Propaganda. The aim of the session was not to support or reject an issue of certain media, rather it was for enlightening the students that news also contains many propaganda practices together with the techniques. The final evaluation regarding the content of the news was on the students. The simulation was started by showing words or critical terms related to propaganda techniques. The words can be seen in table 10:

Table 10. Critical Terms of Propaganda Techniques

\begin{tabular}{|c|c|c|c|}
\hline No & Technique & Critical Terms & Examples \\
\hline 1 & Name Calling & $\begin{array}{l}\text { Labeling, Nick-Name } \\
\text { (either negative or } \\
\text { positive) }\end{array}$ & $\begin{array}{l}\text { Mudslinger, } \\
\text { Heaven Dweller, Infidel }\end{array}$ \\
\hline 2 & $\begin{array}{l}\text { Glittering } \\
\text { Generality }\end{array}$ & $\begin{array}{l}\text { Good slogan, beautiful } \\
\text { (seems good) for a } \\
\text { particular action. }\end{array}$ & $\begin{array}{l}\text { Together to the } \\
\text { greatness, a blessed way }\end{array}$ \\
\hline 3 & Transfer & $\begin{array}{l}\text { A party or someone or } \\
\text { something, such as a } \\
\text { symbol or logo, which is } \\
\text { considered divine to raise } \\
\text { obedience. }\end{array}$ & $\begin{array}{l}\text { Pancasila, flag, logo or } \\
\text { symbol, such as Nazi } \\
\text { and Swastika }\end{array}$ \\
\hline 4 & Testimony & $\begin{array}{l}\text { There is a figurehead that } \\
\text { gives attestation }\end{array}$ & $\begin{array}{l}\text { Artists, politicians, } \\
\text { religious leaders }\end{array}$ \\
\hline 5 & Plain Folks & $\begin{array}{l}\text { A statement or action that } \\
\text { seemingly makes the } \\
\text { speaker closer to certain } \\
\text { people }\end{array}$ & $\begin{array}{l}\text { Having food in small } \\
\text { street vendors and said } \\
\text { that "I used to be } \\
\text { poor.." }\end{array}$ \\
\hline 6 & Card Stacking & $\begin{array}{l}\text { A fact or fact-like that } \\
\text { show, either visual or } \\
\text { verbal }\end{array}$ & $\begin{array}{l}\text { Data, picture of a result } \\
\text { of an action }\end{array}$ \\
\hline 7 & Bandwagon & $\begin{array}{l}\text { Invitation to join with } \\
\text { many people }\end{array}$ & $\begin{array}{l}\text { A survey showing that } \\
\text { " } 9 \text { of } 10 \text { of Indonesian } \\
\text { people..." or pictures of } \\
\text { many people that } \\
\text { perform one activity }\end{array}$ \\
\hline
\end{tabular}

After given explanations and examples regarding propaganda techniques, students then were handed out some online news that contained propaganda techniques and was potential in inviting or teaching religious radicalism. One of the examples of the news can be read below: 


\section{Densus 88 Should Be Countered Physically, A Real One, Not Only By Words}

SOLO (Xxx.com) - Recent atrocity, brutality, and cruelty of Densus 88 in arresting and killing Islamist activists who are alleged as terrorists should be responded seriously by Muslims. Existing Islamic potential should also be synergized to combat Densus 88 collectively.

Muslim Law Experts, for example, should be thoughtful towards the victims of Densus 88 's brutality. They should unite to indict the leaders of Densus 88 who are the actual culprit of any brutal actions and assassination of Densus 88 towards Muslims.

"All law experts should unite and indict the leaders of Densus 88 to International Court of Justice," to quote Ustadz Khoirul RS to XXX.com on Monday (26/5/2103).

The branch leader of FPI Solo Raya added that, apart from law experts who are Muslims, other Muslims that work in different fields should also move and unite to avert the cruelty of Densus 88. For recommendation, advice, critique, and suggestion from the Indonesian Human Rights Commission, Muhammadiyah's leader, MUI's leader, and other figurehead has not been effective.

Ustadz Khoirul explained that there should be another real movement to battle Densus 88 . Densus 88 cannot be fought against with only words. The only attempt left for Muslims is by physical measure.

"It is time to fight openly against Densus 88 . We should counter Densus 88 physically, a real one, not only by words," he emphasized.

To make it possible, added by Ustadz Khoirul, Muslims should agree in viewing the real enemy that should be struck together, namely Densus 88 . For him, one of the ways to fight against Densus 88 is with physical power by standing up for people who are arrested by Densus 88 .

"Wherever they arrest someone or conduct crime scene investigation of a person that is suspected (terrorist -red), Islamic activists should spontaneously and collectively attack the vigilante, Densus 88, with a risk of being martyr (Shahid)," he said.

After being discussed the news, the result can be seen below:

Table 11. Summary of Propaganda Technique Discovered by the Students

\begin{tabular}{|c|c|c|}
\hline No & Teknik & Temuan Siswa \\
\hline 1 & Name Calling & $\begin{array}{l}\text { The culprit behind this cruel action; a group of } \\
\text { vigilante, Densus } 88\end{array}$ \\
\hline 2 & Glittering Generality & $\begin{array}{l}\text { It is time to fight openly against Densus } 88 \text {. We should } \\
\text { counter Densus } 88 \text { physically, a real one, not only by } \\
\text { words }\end{array}$ \\
\hline 3 & Transfer & - \\
\hline 4 & Testimony & The branch leader of FPI Solo Raya \\
\hline 5 & Plain Folks & - \\
\hline 6 & Card Stacking & Densus 88 has not been resisted with words \\
\hline 7 & Bandwagon & $\begin{array}{l}\text { Islamic activists should spontaneously and collectively } \\
\text { attack the vigilante, Densus } 88 \text {, with a risk of being } \\
\text { martyr (Shahid) }\end{array}$ \\
\hline
\end{tabular}

The result of the discussion showed that the students started to identify propaganda techniques in news coverage made by the journalists or other parties behind it (the informants and others). Indeed, not only does this technique appear in provocative 
or radical news, but it also appears in 'normal' news, although it is more difficult to detect. Although not all students were capable of identifying the propaganda technique accurately, they had realized that those techniques were used in the news coverage practice

\section{The Result of Propaganda Test (Post-Simulation)}

After the first propaganda test and simulation of detecting propaganda practice in news, the students performed the second propaganda test using the same question in the first propaganda test. The result can be seen in Table 12, and there were significant changes in the student's answers.

Table 12 Comparison in the Result of Propaganda Tests (Pre-Simulation and PostSimulation)

\begin{tabular}{|c|c|c|c|c|c|c|}
\hline & \multicolumn{3}{c}{ Pre-Simulation } & \multicolumn{3}{|c|}{ Post-Simulation } \\
\hline $\mathbf{1}$ & 1 Point & 2 Point & $\mathbf{3}$ Point & 1 Point & 2 Point & 3 Point \\
\hline $\mathbf{2}$ & 17 & 33 & 50 & $\mathbf{3}$ & $\mathbf{1 1}$ & $\mathbf{8 6}$ \\
\hline $\mathbf{3}$ & 42 & 48 & 10 & $\mathbf{1 3}$ & $\mathbf{1 5}$ & $\mathbf{7 2}$ \\
\hline $\mathbf{4}$ & 26 & 21 & 53 & $\mathbf{7}$ & $\mathbf{5}$ & $\mathbf{8 8}$ \\
\hline $\mathbf{5}$ & 38 & 33 & 29 & $\mathbf{1 1}$ & $\mathbf{7}$ & $\mathbf{8 2}$ \\
\hline $\mathbf{6}$ & 58 & 17 & 25 & $\mathbf{2 0}$ & $\mathbf{3}$ & $\mathbf{7 7}$ \\
\hline $\mathbf{7}$ & 27 & 50 & 23 & $\mathbf{6}$ & $\mathbf{1 2}$ & $\mathbf{8 2}$ \\
\hline & 53 & 17 & 30 & $\mathbf{1 5}$ & $\mathbf{1}$ & $\mathbf{8 4}$ \\
\hline & $\mathbf{2 6 1}$ & $\mathbf{2 1 9}$ & $\mathbf{2 2 0}$ & $\mathbf{7 5}$ & $\mathbf{5 4}$ & $\mathbf{5 7 1}$ \\
\hline
\end{tabular}

The table above shows that there was a significant transformation in the students' answers. The students had started to realize the use of propaganda. That is to say, the student had started to have propaganda awareness. The result showed the average score of the students that changed significantly. Starting from a middle level on average, to mild, as shown in table 13.

Table 13. Comparison in the Result of Propaganda Tests (Pre-Simulation and PostSimulation) from the Average Score

\begin{tabular}{|l|l|c|c|}
\hline No & \multicolumn{1}{|c|}{ Score } & Pre-Simulation & Post-Simulation \\
\hline $\mathbf{1}$ & Mild $(7-11$ poin $)$ & 7 & $\mathbf{7 8}$ \\
\hline $\mathbf{2}$ & Medium $(12-16$ poin $)$ & 73 & $\mathbf{1 6}$ \\
\hline $\mathbf{3}$ & High $(17-21$ poin $)$ & 20 & $\mathbf{6}$ \\
\hline
\end{tabular}

source: The researcher's data

\section{Conclusion}

The research concludes 4 points. These four points were obtained After propaganda test conducted before the simulation to identify the level of the influence of the media had towards the student by giving the student some question that contains a basic propaganda techniques; a simulation test to educate the students regarding the most common propaganda techniques, which were usually found daily activity, and how to dispel it in news coverage; and the second simulation to track their progress.

1. Social media use in students was relatively high because of the more accessible access to the internet. All informants in the research were active social media users. They know how to share a news link and often got shared news links although not all the informants read and share the link. 
2. In the pre-simulation propaganda test, the average score of propaganda influence on the students was reasonably high. It implies that the propaganda shared through media affects the views, attitudes, and behavior of the students.

3. In simulation to identify propaganda practices in media, the student generally understood well typical propaganda technique found in the news. It can be seen from the students' capability in analyzing propaganda techniques, which was found in the news that was set as examples. Another evidence is the significant differences in the post-simulation propaganda test, which started from low to high. The result of the post-simulation test demonstrated that providing understanding propaganda can raise the student's propaganda awareness.

4. Propaganda awareness is a useful provision for the students to respond to different content on social media, which its validity is hard to check. The reason is that many of them are not a result of journalism products and following the journalism process, ranging from verification, check and recheck, and cover both sides. Awareness of propaganda also gives knowledge to the student to be careful in receiving and sharing information on social media. Nevertheless, supervising and monitoring from the parents, educators, religious leaders, and the government on religious content are still essential. The family is the last main border in barring radicalism. Family is an individual that is closest to the students. The role of parents is vital for children's development. (Kusuma,2018).

The importance of propaganda awareness has not been widely realized by many Indonesian people, whether general or academic. It is different from the media literacy movement that has been performed by many people and groups. Propaganda awareness and media literacy have almost the same vision, namely to educate the audience regarding the content in the media.

However, while media literacy focuses on media, propaganda, despite its massive use in mass media, is quite prevalent outside of the scope of media since propaganda has numerous forms. In addition, propaganda awareness can also educate understanding of the media contents deeply so that the audience can not only avoid media exposure but also have the capability to digest the content of the media more effectively. It is relevant since many radical movements conduct its propaganda using false, and even intentionally false, interpretation of religious propositions.

\section{Acknowledgment}

The research thanks Lembaga Penelitian dan Pengabdian Masyarakat (LPPM) UIN Sunan Kalijaga Yogyakarta that has funded the research. The researcher also thanks other parties that have helped the research to finish this research.

\section{References}

Choudhury, T. (2007). The Role of Muslim Identity Politics in Radicalisation. London : Departement for Communicaties and Local Government.

Cull, Nicholas J.; David Culbert \& David Welch. (2003). Propaganda and Mass Persuasion, A Historical Encyclopedia, 1500 to the Present. Santa Barbara California : ABC-CLIO.

Irwanto. (2006). Focus Group Discussion. Jakarta : Pustaka Yayasan Obor Indonesia. Jowett, Garth S. \& Vitoria O’Donnell. (2006). Propaganda and Persuasion.4th Edition. 
California : Sage Publications.

Kunandar, Alip. (2012). Teknik Propaganda Anti-Yahudi NAZI Jerman, Jurnal Komunikasi Profetik 5(2).

Kusuma, Rina Sari dan Nur Azizah. (2018). Melawan Radikalisme melalui Website, Jurnal ASPIKOM 3(5).

Krueger, Richard A \& Casey, Marry Anne. (2009). Focus Groups, A Practical Guide for Applied Research. 4th Edition. California : Sage Publication.

McQuail, Dennis. (2011). Teori Komunikasi Massa. Edisi 6.Buku 2. Jakarta : Salemba Humanika.

Severin, Werner J.dan James W. Tankard. (2011). Teori Komunikasi, Sejarah, Metode dan Terapan di Dalam Media Massa, Edisi ke-5. Jakarta : Kencana.

Shabo, Magedah E. (2008). Techniques of Propaganda and Persuasion. USA : Prestwick House Inc.

Simangunsong, Benecditus A. (2016). Interaksi Antarmanusia Mellaui Media Sosial Facebook Mengenai Topik Keagamaan, Jurnal ASPIKOM 3(1).

Sulistyo, Adi. (2014). Radikalisme Keagamaan dan Terorisme dalam www.academia.edu diakses pada 5 April 2014

Van Dijk, Jose. (2013). The Culture of Connectivity, A Critical History of Social Media. New York : Oxford University Press. 